\title{
'TILIK': A STUDY OF POWER AMONG JAVANESE WOMEN THROUGH GOSSIP
}

\author{
Putri Rindu Kinasih
}

English Department, Faculty of Language, Universitas Bunda Mulia, Tangerang 15143, Indonesia

A RTICLE INFO

Keywords:

Gossip

Power

Javanese women

Literature

Movie

Article History:

Received: $13 / 09 / 2021$

Accepted: 26/11/2021

Available Online:

$30 / 11 / 2021$

\begin{abstract}
A B S T R A C T
Gossip plays a crucial part in our communicative and social behavior as it is thought to be a manifestation of any 'ordinary' everyday life. Interestingly, the portrayal of gossip in Javanese culture can be found in the recent viral short movie Tilik (The Ladies on Top). Unfortunately, contemporary interpretations and discussions about Bu Tejo often focus only on what gossip is about and its negative effect on the image of women. None of them observed the relation between gossip and power. Thus, the study aims to analyze gossip in Tilik movie by using the concept of power among Javanese women. The writer used the qualitative method. The writer focused on the theory of gossip and power; and used the concept of power among Javanese women proposed by Handayani and Novianto. This research revealed that gossip in Tilik becomes the weapon of choice in the female arsenal due to the rivalry between $\mathrm{Bu}$ Tejo and Dian. Bu Tejo's negative attitude towards Dian can be seen as a political tactic for Javanese women, and the personal is political. Lastly, the acts of gossiping in the movie match with the concept of how Javanese women play the game of power through -srawung (socialization).
\end{abstract}

2442-305X / (C) 2021 The Author, this is open access article under the (CC-BY-NC) license (https://creativecommons.org/licenses/by-nc/4.0/), DOI: 10.19105/ojbs.v15i2.5090

\footnotetext{
* Corresponding Author:

Email address: pkinasih@bundamulia.ac.id (P. R. Kinasih)
}

\section{A. Introduction}

Gossip plays a very important part in our communicative and social behavior as it is thought to be a manifestation of any 'ordinary' everyday life. Gossip is something that everyone experiences, contributes to, and presumably intuitively understands. Gossip is often valuable, and even sometimes unavoidable to be part of communication. Humans require information about people around them to function efficiently in a complex social environment. Since it is impossible to be present and absorb the information directly in every event.

Foster added that many people are eager to pick it up through a medium which is called gossip. Interestingly, although there are numerous social sanctions against it, gossip is 
omnipresent. ${ }^{1}$ Gossip is practiced all over the world, including in Java, Indonesia. The portrayal of gossip in Javanese culture can be found in the recent viral short movie Tilik (The Ladies on Top).

Due to its incisiveness in representing gossip as a relevant social behavior globally, Tilik has been chosen as the official selection for the film festival World Cinema Amsterdam, 2019. In addition, not only Tilik was chosen for the official selection of the Jogja-Netpac Asian Film Festival in 2018; it was also won the prominent award Piala Maya 2018 under the category of 'Film Pendek Terpilih'. Since its premiere date 17 August 2020, more than 26 million people had been tantalized to watch the main character, $\mathrm{Bu}$ Tejo, gossiping with a group of women. Tempo magazine stated that before Tilik was aired online, short movies in Indonesia have not taken into the account Indonesian audience. Thus, Merdeka claimed that Tilik's phenomenon has successfully created momentum to cultivate the ecosystem of short movies in Indonesia. $^{2}$

Produced by Yogyakarta-based production house Racavana Films, in collaboration with the Yogyakarta Cultural Agency, Tilik richly shows an example of how 'gossip', as a human universal has become a prevalent part of all times and cultures.

Unfortunately,

recent

\footnotetext{
${ }^{1}$ Eric K. Foster, "Research on Gossip: Taxonomy, Methods, and Future Directions," Review of General Psychology 8, no. 2 (2004): 78-99, https://doi.org/10.1037/1089-2680.8.2.78.

2 Moyang Kasih Dewi Merdeka, "Tilik dan Riwayat Film Pendek Kita," Tempo, September 4, 2020, https://majalah.tempo.co/read/selingan/161344/tilikdan-riwayat-film-pendek-kita.
}

interpretations and discussions about $\mathrm{Bu}$ Tejo's malicious act of gossiping often focus only on what gossip is about and its negative effect on the image of women. Suryakusuma from Jakarta Post said that the movie putting the women down as it consciously aims of highlighting the women's character defect. ${ }^{3}$

Pambudy from Kompas even claimed that the stereotypes of women featured in Tilik are multi-layered, among others, as gossipers, lack of transcendent abilities, and a source of slander. ${ }^{4}$ In other words, few people see further why the gossip happens and the role it plays in the larger sociopolitical aspect of community life. Whilst, gossip as a part of language, portrays the important issue of power. To date, there has been limited research that investigates the relationship between gossip and power in the short movie Tilik.

In 2020, a study of Tilik short movie has been done by Christina, in which she elaborated Bu Tejo's utterance based on the theory of speech act proposed by Searle. ${ }^{5}$ The analysis revealed that representative speech acts dominate the utterances made by $\mathrm{Bu}$ Tejo in the movie. She made her words to fit the world she believed in. Also, Bu Tejo hardly ever

\footnotetext{
3 Julia Suryakusuma, "Tilik', Sexist Stereotypes and Our Collective Insanity," The Jakarta Post, September 16, 2020, https://www.thejakartapost.com/academia/2020/09/ 16/tilik-sexist-stereotypes-and-our-collectiveinsanity.html.

4 Ninuk M Pambudy, "Menilik Lagi "Tilik"," Kompas.ld, September 12, 2020, https://www.kompas.id/baca/opini/2020/09/12/menil ik-lagi-tilik/.

${ }^{5}$ Christina, "The Analysis of Bu Tejo's Language in Short Movie 'Tilik,'” METAPHOR 3, no. 1 (2020): 56-67.
} 
made a declaration speech act, only once she said it in the entire movie when she handed Gotrek some money from her husband. Then, Bu Tejo's commissive speech acts were seen as mostly negative as she used more threats and refusals in her utterances. Not only that, but Bu Tejo also performed directive speech acts in many scenes which suits her right as she was portrayed as the dominant woman among the others. Lastly, Christina wrote that only a little part of Bu Tejo's utterance is done in indirect speech acts. Christina believed that the indirect speech acts do not represent Bu Tejo's Javanese layeredpoliteness, but it depicts her insecurity as her husband plans to join the upcoming sub-district head election.

Furthermore, a psychological study has been done by Inayaturrobbani. ${ }^{6}$ She analyzed the function of gossip in Tilik by using Self-Concept Enhancing Tactician (SCENT) theory which explicitly assigns that human do specific activities, including gossip, to raise personal and self-image and concept social in society. In her study, Inayaturrobbani wrote that $\mathrm{Bu}$ Tejo did a downward comparison as she gossips about $\mathrm{Bu}$ Lurah. Bu Tejo unwittingly accentuates her positive traits which are not owned by Bu Lurah. For example, Bu Tejo has a husband while $\mathrm{Bu}$ Lurah doesn't have one. Also, Bu Tejo claimed that $\mathrm{Bu}$ Lurah is ill and weak while Bu Tejo and her husband are in a good health. Thus, through the conversation, it can be

6 Fakhirah Inayaturrobbani, "Memahami Fungsi Gosip Dalam Masyarakat Melalui Film Pendek 'Tilik," TONIL: Jurnal Kajian Sastra, Teater dan Sinema 17, no. 2 (2020): 41-54, https://doi.org/10.24821/tnl.v17i2.4353. seen that there is ongoing self-promotion. Additionally, in the movie, Dian raises concern so that the women gossip with the aim of self-protection. In conclusion, the study found that gossip serves as promotion and self-protection, both directly or indirectly.

Lastly, Nurhablisyah and Susanti conducted a content analysis study of Tilik by using the film narrative theory of David Bordwell. $^{7}$ First, they wrote that in film narration characters are built from the dialogue and elements attached to the character itself. Interestingly, despite the social difference that is shown between $\mathrm{Bu}$ Tejo and the other women, they are all can express their opinion. Whilst, Nurhablisyah, and Susanti believed that in real life in Central Java, openness during conversation is considered as something uncommon. ${ }^{8}$ Secondly, the study found that the director consistently brings up 'hoax' as the theme in every segment including the shady information about Dian.

Moreover, the scene when Dian is shown with an older man who turns out to be addressed as Pak Lurah, adds complication toward the issue of a hoax as it questions who's telling the truth and doesn't. Lastly, Nurhablisyah and Susanti also highlight the downside of the movie as they claimed that Tilik failed to calculate the time-lapse logically.

\footnotetext{
${ }^{7}$ Nurhablisyah and Khikmah Susanti, "Analisis Isi 'Tilik' Sebuah Tinjauan Narasi Film David Bordwell," Jurnal IImu Komunikasi UHO: Jurnal Penelitian Kajian IImu Komunikasi dan Informasi 5, no. 4 (2020): 315-29, https://doi.org/10.52423/jikuho.v5i4.14460.

${ }^{8}$ Nurhablisyah and Susanti, 328.
} 
Assumingly, if the women arrived in the hospital by late afternoon, then they should not go to Pasar Bringharjo for it should be closed soon.

On the whole, a considerable amount of research had successfully spotlighted various interpretations of the hidden issue in Tilik. However, none of the studies above really observed how gossip is analyzed with its relation to power. Christina elaborated Bu Tejo's utterance based on the theory of speech act proposed by Searle. ${ }^{9}$ Inayaturrobbani found that gossip in Tilik serves as promotion and self-protection by using the model theory Self-Concept Enhancing Tactician (SCENT). ${ }^{10}$ Finally, Nurhablisyah and Susanti did a content analysis study of Tilik by using the film narrative theory of David Bordwell. ${ }^{11}$ Therefore, the question about the portrayal of power and gossip remains unanswered.

Giardinni and Wittek in The Oxford Handbook of Gossip and Reputation, gossip and reputation have long been linked to power and status, more specifically whereas research on reputation mainly explores its interrelationship with status, prestige, or esteem. ${ }^{12}$ So, gossip is a highly efficient

\footnotetext{
${ }^{9}$ Christina, "The Analysis of Bu Tejo's Language in Short Movie 'Tilik."”

10 Inayaturrobbani, "Memahami Fungsi Gosip Dalam Masyarakat Melalui Film Pendek 'Tilik.'”

11 Nurhablisyah and Susanti, "Analisis Isi 'Tilik' Sebuah Tinjauan Narasi Film David Bordwell."

12 Francesca Giardini and Rafael Wittek, "Introduction: Gossip and Reputation-A Multidisciplinary Research Program," in The Oxford Handbook of Gossip and Reputation, ed. Francesca Giardini and Rafael Wittek (New York: Oxford University Press, 2019), 10.
}

and impactful mechanism by which reputations are created, maintained, and altered. The selective and strategic use of gossip increases a gossiper's power, for example, his or her ability to influence others. ${ }^{13}$ Additionally, it is argued that individuals are especially interested in gossip about higher-status individuals, rivals (for potential exploitative value), and potential mates. ${ }^{14}$ In addition, study showed that gossip may elevate the social status of the gossiper through inferred informational power. ${ }^{15}$ Consequently, gossip (in which socially ostracizing rivals) becomes the weapon of choice in the female arsenal. ${ }^{16}$ Although gossip can be used to gain power, it should be noted that that gossip may become a costly strategy. ${ }^{17}$

\footnotetext{
${ }^{13}$ Sally D. Farley, "Is Gossip Power? The Inverse Relationships between Gossip, Power, and Likability," European Journal of Social Psychology 41, no. 5 (2011): 574-79, https://doi.org/10.1002/ejsp.821.

${ }^{14}$ Frank McAndrew and Megan A. Milenkovic, "Of Tabloids and Family Secrets: The Evolutionary Psychology of Gossip," Journal of Applied Social Psychology 32, no. 5 (2002): 1064-82, https://doi.org/10.1111/j.1559-1816.2002.tb00256.x.

${ }^{15}$ Roy F. Baumeister, Liqing Zhang, and Kathleen D. Vohs, "Gossip as Cultural Learning," Review of General Psychology 8, no. 2 (2004): 111-21, https://doi.org/10.1037/1089-2680.8.2.111.

16 John Archer, "Sex Differences in Aggression in Real-World Settings: A MetaAnalytic Review," Review of General Psychology 8, no. 4 (2004): 291-322; Catharine Cross and Anne C. Campbell, "Violence and Aggression in Women," in The Evolution of Violence, ed. Todd K. Shackelford and Ranald D. Hansen (New York: Springer, 2014), 211-32.

17 Sally D. Farley, "On the Nature of Gossip, Reputation, and Power Inequality," in The Oxford Handbook of Gossip and Reputation, ed. Francesca Giardini and Rafael Wittek (New York: Oxford University Press, 2019), 343-58.
} 
In addition, none of the previous studies above discussed the pattern of gossip. Lestari et al. argued that Javanese women have the habit of behaving and speaking differently from others because the behavior is affected by their interests and problems that bind together Javanese women. ${ }^{18}$ They believed that gossiping activities by Javanese women showed the structure of phasing and the use of specialized languages that showed the identity of Javanese people. What is more, the diplomatic strategy of Javanese women is highly supported by the ability to build relations through srawung. Srawung or socialization becomes a crucial thing so that women may secure their value claiming in negotiation, and finally inveigle the public. In the concept of Javanese women's power, it must be understood that the authority is not shown formally/ publicly/ impersonally, but for them, the personal is political. ${ }^{19}$

Considering this, the researcher is interested in analyzing gossip in Tilik movie with the concept of power among Javanese women proposed by Handayani and Novianto. ${ }^{20}$ Therefore, this research is aimed to know what extent the relation of power and gossip is portrayed from Tilik and how gossip in Tilik movie can be analyzed with the concept of power among Javanese women.

18 Prembayun Miji Lestari et al., "The Structure Pattern of Ngrasani 'Gossiping' by Javanese Women in Indonesia," Australasian Journal of Educational Technology 35, no. 1 (2019): 116-29.

${ }^{19}$ Christina S. Handayani and Ardhian Novianto, Kuasa Wanita Jawa, ed. Retno Suffatni (Yogyakarta: PT LKiS Printing Cemerlang, 2004), 204.

${ }^{20}$ Handayani and Novianto, 157, 204-205.

\section{B. Method}

This research was a qualitative research. The researcher selected the short movie Tilik. This movie portrays gossip in Javanese culture. As opposed to previous researches and reviews about Tilik. This research focused more on the theory of gossip and power and the concept of power among Javanese women proposed by Handayani and Novianto. ${ }^{21}$

They noted that Javanese women build power not by fighting against power but by playing within the power space itself. $^{22}$ Moreover, Javanese women do not need to use weapons that can kill to have power. Power for Javanese women is interpreted as distributing humans in a field and use. Power for Javanese women means having a duty to take care of life so that what is needed is a continuous mechanism that regulates and improves things in her space. In this kind of power, Javanese women must be able to qualify, measure, evaluate the enemy, not manifest themselves as murderers. ${ }^{23}$

Additionally, in Javanese women's power, power is not considered as something that is shown publicly/ formally/ impersonally, but personal is political. In other words, power can be determined personally because diplomacy and bargaining take place in the most private of spaces. This process occurs starting from the micro (family) scope and extends to the macro (public) sphere through matrifocal networks through srawung

\footnotetext{
${ }^{21}$ Handayani and Novianto, 157, 204-205.

22 Handayani and Novianto, 203.

${ }^{23}$ Handayani and Novianto, 213.
} 
(socialization). ${ }^{24}$ Srawung becomes a crucial event so that women have bargaining value and blend in with the public. Besides widening their knowledge, this network also functions as a power to lobby people for Javanese wives. ${ }^{25}$

No wonder then that the position of the husband in the office is largely determined by the diplomacy of women in the network between them. Wives who are never involved in srawung (socialization) will not only be ostracized, but the most important thing is that they will not have access to participate in determining their husbands' position in the office. Again, the empirical fact about women's behavior in managing their power is that they will not appear formally. On the contrary, Javanese women control their power by slipping between narrow gaps that are not visible to the public. ${ }^{26}$

This theory was chosen because Indonesia is a multiethnic and multicultural nation. Thus, the implication of this diversity is that gender must be understood in a particular cultural context. The data collection procedure of this research was started by watching Tilik short movie three times to be able to grasp the essence of the story. Next, the writer collected the transcript of the dialogue by downloading subtitles and find samples (screenshot) that match the theory. Lastly, the writer listed all data subtitles and screenshots from the film and classify them as proof in analyzing the problem of this research.

\footnotetext{
24 Handayani and Novianto, 204-205.

${ }^{25}$ Handayani and Novianto, 157.

${ }^{26}$ Handayani and Novianto, 205.
}

\section{Results}

\section{Power and Gossip}

To understand how gossip works in Tilik movie, it should be realized that a single, concrete utterance is always given in a value-and-meaning cultural context, whether it be scientific, artistic, political, or in the context of a situation from everyday personal life. In other words, as it has been stated by Bakhtin, there are no neutral utterances, nor can there be. ${ }^{27}$ From the movie, gradually it is revealed that Bu Tejo's husband is about to run for the next district mayor (lurah) election.

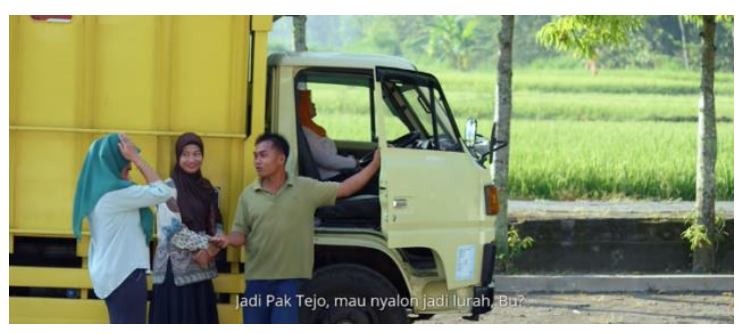

Fig. 1. Gotrek is afraid to take the money from Bu Tejo [10:46/32:36]

Bu Tejo : "Tur ya, sakjane ki [cough] nek misal... [cough] ya warga sing ngejok'e bojoku nggo dadi anu... apa... lurah ngono kaya Gotrek apa piye, kaya Yu Ning ngono dadi tim sukses ya, masa aku ya nolak. Haha, ra penak tho."

(Well, if people want to, like, for him to be elected to be the Lurah, let's say like Gotrek, or Yu Ning would want to be in the campaign team, it would be disrespectful to say no.) [11:00/32:34]

27 Mikhail Mikhailovich Bakhtin, Art and Answerability, ed. Michael Holquist and Vadim Liapunov (Austin: The University of Texas Press, 1990), 292 
From the dialogue above, it can be seen that $\mathrm{Bu}$ Tejo did not explicitly proclaim her husband's agenda. She kept on denying that all her actions, her kindness was motivated by her need to get as much support as she can. The dialogue above shows that she accepted any help or support given to her husband from Gotrek or Yu Ning if they were willing to be involved in a campaigned team. In addition, it is also should be understood that in the upcoming election, Dian was also seen as another eligible candidate.

$\begin{array}{cl}\text { Gotrek } & \begin{array}{l}\text { : "Lha, saiki ngene wae, Bu..." } \\ \text { (Let's settle this) }\end{array} \\ \text { Bu Tejo } & \begin{array}{l}\text { : "Apa?" } \\ \text { (What?) }\end{array} \\ \text { Gotrek } \quad \text { :Nek sing dadi lurah Dian } \\ \text { wae, piye?" } \\ \text { (How if we elect Dian to be } \\ \text { Lurah?) }\end{array}$

Bu Tejo : "Ya Allaaaah ... ya ojo, tho ..." (Oh God, no. Please no...)

Gotrek : "Mesti akeh sing seneng. Bapak-bapak mesti dho milih kabeh lho"

(All men would vote for her for sure)

Bu Tejo : "Ya Allah, ya ampun... (Oh my God, please... astagfirullah) [12:07/32:34]

From the dialogue above, it can be seen from the dialogue above that Dian is treated as a contender, a rival. When $\mathrm{Bu}$ Tejo is trying to gain support from Yu Ning and Gotrek, all of a sudden Gotrek came up with an idea that Dian should become the next district mayor. Gotrek even added that Dian would be voted by many men in the election. As expected, Bu Tejo directly rejected Gotrek's suggestion.
Bakhtin believed that all words have the taste of a profession, a genre, a tendency, a party, a particular person, and many more. On the whole, all words and forms are populated by intentions. ${ }^{28}$ In Tilik case, it should be kept in mind that there is a rivalry going between $\mathrm{Bu}$ Tejo and Dian. Once the state of affairs, the upcoming election is grasped, then it would be easier to see how Bu Tejo's gossip relates to power.

Secondly, gossip is a highly efficient and impactful mechanism by which reputations are created, maintained, and altered. Farley also believed that the selective and strategic use of gossip increases a gossiper's power, for example, his or her ability to influence others. $^{29}$ The example of Bu Tejo's attempt in influencing others can be seen from the scene when she talking about $\mathrm{Bu}$ Lurah below.

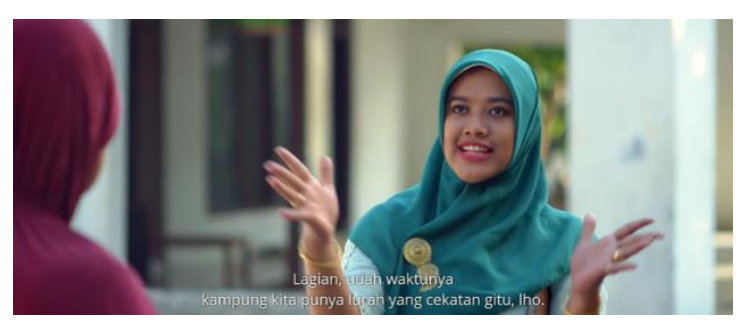

Fig. 2. Bu Tejo persuades people that the village needs a handy leader [11:54/32:36]

Bu Tejo : "Tenan iki nggo kowe Trek, tenanan ya Allah. Tur ya saiki ya dho mikir, heh, mbok ya dho mikir, Bu Lurah kuwi lho, $\mathrm{Bu}$ Lurah kuwi lak ya wis gerah bola-bali tho. Mesak'ke Iho Bu Lurah ki..."

\footnotetext{
28 Mikhail Mikhailovich Bakhtin, "The Dialogic Imagination: Four Essays," in Theory of the Novel, ed. Michael McKeon (Baltimore: The John Hopkins University Press, 2000), 321-54.

${ }^{29}$ Farley, "On the Nature of Gossip, Reputation, and Power Inequality," 343.
} 
(Really, for God's sake, it's for you. Anyway, let's think about $\mathrm{Bu}$ Lurah. She often sick. Poor her)

Unknown-

character: "Alhamdulilah wis Dzuhur-an. Iki dho ngomongno apa tho, Bu?"

(What are you guys talking about?)

$\mathrm{Bu}$ Tejo : "Wis ngono ki uripe dhewe. Nduwe anak siji kuwi wae ya imbas-imbis ngono kae. Anak lanang'e kae ho'oh, tho? Dadine wis wayahe Bu Lurah kuwi leren. Mesak'ke Iho, Bu Luhar ki..."

(On top of that, she's living alone. Her only son couldn't be counted on, right? It's time for her to het some rest. I feel sorry for her)

Yu Sam : "Oalah...Bu Lurah..." (Ooh, Bu Lurah...)

Yu Ning : "Padune ben Pak Tejo sing dadi lurah, yo ora?"

(That's what you want, for your husband to replace her, right?)

Bu Tejo : "Eh, ya ora. Kuwi mau mesak'ke wae. Tenan, ho'oh tho. Tur ya, wis wayahe desane dhewe ki butuh lurah sing cak-cek sat-set ngono kae Iho, ho'oh tho? Tur ora single."

(No, it's not that. I just feel sorry for her. Besides, it's time our village to have a handy Lurah. And, not the single one)

Yu Tri : "Nek kuwi setuju aku."

(I agree with it)

Bu Tejo : "Nek single kuwi nggawa uripe dhewe wae abot, ho'oh ora? Saiki coba ta takon."

(A single person can't even get his/her live together.) [11:45/32:34]
From the dialogue above, it can be seen how $\mathrm{Bu}$ Tejo initiated gossip. $\mathrm{Bu}$ Tejo opens the gossip with a challenge to the people around her to rethink and reconsider Bu Lurah's health. She also brings up the condition of Bu Lurah's son whom she considers unreliable. Even though she denies her intention when $\mathrm{Yu}$ Ning directly confronts her motive, she adds a supporting statement in which she highlights that the village needs a handy lurah.

Lastly, she emphasizes the agenda; which is to take down Bu Lurah's authority and to prevent Dian from getting the villagers' vote. Bu Tejo stressed the point that the village must not be governed by a single person, in this case, Dian. Moreover, it can be seen that from the beginning $\mathrm{Bu}$ Tejo is trying to defame both Bu Lurah's and Dian's reputation. When the villagers agree that the next leader must be healthy and must not be single at the same thus, Bu Tejo's chance of becoming a wife of the next leader is getting higher.

The case above is aligned with the theory that among females, the goal of gossip is to exclude competitors from a social group and damage the competitor's ability in maintaining a reliable social network of her own. ${ }^{30}$ Thus, aligned with the previous research, gossip in Tilik movies becomes the weapon of choice in the female arsenal. ${ }^{31}$

\footnotetext{
${ }^{30}$ Francis T. McAndrew, "The 'Sword of a Woman': Gossip and Female Aggression," Aggression and Violent Behavior 19, no. 3 (2014): 196-99, https://doi.org/10.1016/j.avb.2014.04.006.

31 John Archer, "Sex Differences in Aggression in Real-World Settings: A MetaAnalytic Review,"
} 
Thirdly, Jaeger, Skleder, Rind, and Rosnow (as cited in Farley) showed that people with a high propensity to gossip are often quite powerful individuals at the center of communication networks. ${ }^{32}$ Compared to $\mathrm{Yu}$ Ning, a person who is constantly correcting misinformation that spreads quickly in the village, Bu Tejo gains more support and acceptance. The example of the women's approval can be seen from the dialogue below:

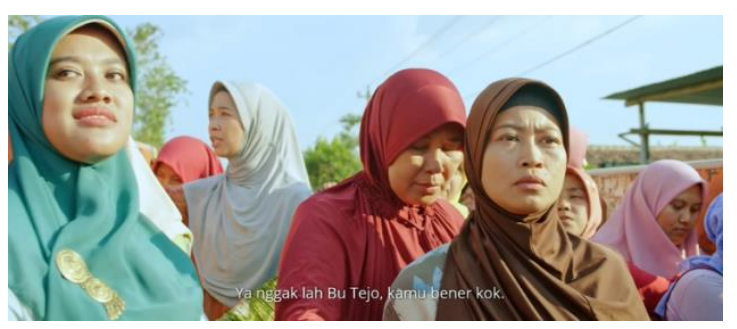

Fig. 3. Bu Tri and Yu Nam give their approval of Bu Tejo's action [19:52/32:34]

Yu Ning : “Ah, gen'e... yen Pak Tejo dirasani ki Bu Tejo ra trima. Ngono kuwi senengane ngrasani Dian, ora ana buktine wae kok."

(So, you're upset when someone talks about your husband. Why did you do that to Dian? You have no proof at all).

Bu Tejo : "Yu Sam, saiki aku arep takon. Ket mau, aku takontakon soal Dian, Yu Ning kuwi mesti maido ora?"

(Yu Sam, let me ask you about this. When I asked around about Dian, was $Y u$ Ning always making a big deal about it?)

Review of General Psychology 8, no. 4 (2004): 291-322; Catharine Cross and Anne C. Campbell, "Violence and Aggression in Women," in The Evolution of Violence, ed. Todd K. Shackelford and Ranald D. Hansen (New York: Springer, 2014), 211-32.

${ }^{32}$ Farley, "On the Nature of Gossip, Reputation, and Power Inequality," 348.

\author{
Yu Sam : "Ho’oh." \\ (Yes, she was). \\ Bu Tejo : "Terus, nek aku ki ngenehi \\ informai soal Dian, apa aku ki \\ keleru, heh?" \\ (Then, when I gave info about \\ Dian, was it wrong?)
}

Bu Tri : "Mboten, Bu Tejo, jenengan iku leres kok. Yen menurutku Iho, Bu Tejo, informasi perkara Dian kuwi migunani." (You're not wrong at all, Bu Tejo. In my opinion, any info about Dian is useful).

Bu Tejo : "Nah, pinter berarti kowe."

(Then, you're a smart one) [19:52/32:34]

From the dialogue above, it can be seen how $\mathrm{Bu}$ Tejo keeps on getting support and approval from the women even after $\mathrm{Yu}$ Ning also constantly correcting every information that has been shared by $\mathrm{Bu}$ Tejo. Interestingly, in the previous scenes in the movie, Bu Tejo has been warned by Yu Ning and Yu Sam that as Indonesian they believe that 'a slander is more dangerous than murder.' Yet, from the dialogue above, when $\mathrm{Yu}$ Ning highlighted that $\mathrm{Bu}$ Tejo has no proof the women are backing $\mathrm{Bu}$ Tejo up. Both $\mathrm{Yu}$ Sam and $\mathrm{Bu}$ Tri stand up for her when she is asking for confirmation.

In other words, compared to $\mathrm{Yu}$ Ning, Bu Tejo can be considered more influential. Bu Tejo is quite powerful at the center of communication networks. She can swift Yu Nam's belief from scolding her (reminding $\mathrm{Bu}$ Tejo that slander is more dangerous than murder) into supporting her in badgering Yu Ning's true motive in defending Dian. 
In short, Bu Tejo can make these women back in her side through gossip. The support that $\mathrm{Bu}$ Tejo gains are essential in securing her position in the upcoming election, and eliminating Dian as her rival. Thus, the example above aligns with the theory argued gossip can be used to gain power because it influences behavior, fosters cooperation, and increases group affiliation, ${ }^{33}$ it also provides the initial boost to a person's self-esteem and reputation. ${ }^{34}$

\section{The power of Javanese women}

The diplomatic strategy of Javanese women is highly supported by the ability to build relations through srawung (socialization). Through srawung, one can spread the impact beyond the ordinary neighborhood. Through the network created through srawung, the wives can have the access to shape the husband's carrier. ${ }^{35}$ Here lies the reason why gossip in Tilik should be seen in a broader context, at least more than just a signal that a group disapproves of someone's behavior.

On the contrary, the conversation that happened on the truck along the way to the hospital should be seen as a form of srawung. Through the conversation with the women on the truck, it can be clearly seen how Bu Tejo tries to shape

\footnotetext{
${ }^{33}$ Richard Huskey, "Gossip: More than Just Trash Talk," Current Biology 31, no. 12 (June 21, 2021): 783-86, https://doi.org/10.1016/j.cub.2021.04.048.

34 McAndrew and Milenkovic, "Of Tabloids and Family Secrets: The Evolutionary Psychology of Gossip, 5."

${ }^{35}$ Handayani and Novianto, Kuasa Wanita Jawa, 205.
}

her husband's carrier. The example can be seen from the scene below:

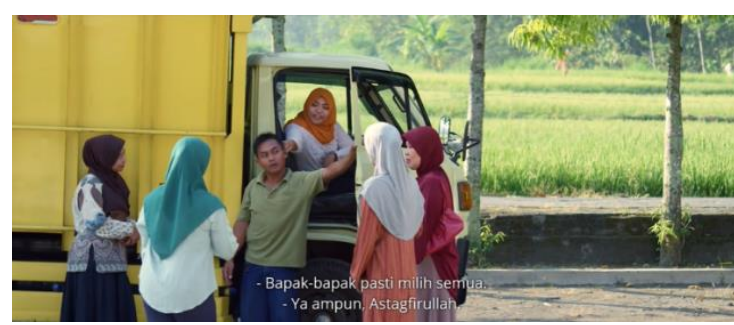

Fig. 4. Bu Tri is looking for support while socializing [12:07/32:34]

Gotrek : :Nek sing dadi lurah Dian wae, piye?"

(How if we elect Dian to be Lurah?)

Bu Tejo : "Ya Allaaaah... ya ojo, tho..."

(Oh God, no. Please no...)

Gotrek : :Mesti akeh sing seneng. Bapak-bapak mesti dho milih kabeh Iho!"

(All men would vote for her for sure!)

Bu Tejo : "Ya Allah, ya ampun... astagfirullah.."

(Oh my God, please... astagfirullah...)

Gotrek's wife : "Ora usah reka-reka..." (Don't you dare to think about that ...)

Bu Tejo : "Aja banget, aja... amitamit amit-amit... Ya Allah, desane dhewe isa ambyar nek kaya ngono. Nek entuk lurah kaya Dian ngono kuwi."

(Please, don't let it happen... Knock-knock wood... Oh God, our village would become chaotic if we have a lurah like Dian.)

Gotrek's wife : “lya, aku setuju karo Bu Tejo, aja Dian. Bojoku iki Iho senengane nggateli... senengane lirak-lirik..." 
(Yes, I agree with you, $\mathrm{Bu}$ Tejo. Don't pick Dian. My husband is so flirty. He always gets caught glancing at women ...)

Bu Tejo : "Yo aja tukaran ning kene "

(Don't argue here, guys...)

Gotrek's wife : "Jewer meneh, po piye?"

(Do you want more?) [12:07-12:41/32:34]

It is highly believed that through the socialization in srawung, Javanese women can widen their knowledge, and expand their power as they gain crucial issues. ${ }^{36}$ From the dialogue above, we can see that $\mathrm{Bu}$ Tejo gains knowledge about the villagers' attitudes towards Dian, her rival. When Gotrek throws out the idea of Dian being the next leader, most of the women strongly object to it. Through the conversation, $\mathrm{Bu}$ Tejo may conclude that most of the women would not agree if Dian should become the leader. Consequently, $\mathrm{Bu}$ Tejo's husband's chance of becoming the next lurah is getting higher. This finding matched with the notion which stated that it is not surprising that the husband's positions in the local government unit are critically determined by the diplomatic activity during srawung. ${ }^{37}$

Secondly, not only does $\mathrm{Bu}$ Tejo minimize Dian's chance of becoming the next lurah, but also, she instills the idea that her husband is the most ideal candidate for becoming the next lurah. In addition, as it can be seen from Figure 2,

\footnotetext{
${ }^{36}$ Handayani and Novianto, 157.

${ }^{37}$ Handayani and Novianto, 157.
}

through srawung Bu Tejo emphasizes that her husband fits with the criteria of an ideal lurah because her husband is handy, healthy, and not single. Moreover, when she gives the money to Gotrek, she also convinces him that her husband is a sensible person whose principle is: talk less do more. Consequently, it is okay for Gotrek to take the extra money from his husband as it symbolizes how her husband reacts in emergencies. His husband is willing to give money. Thus, the finding aligns with the idea that through srawung, Javanese women may secure their value claiming in negotiation, and finally inveigle the public. ${ }^{38}$ In short, not only Bu Tejo gains knowledge through socialization, but she also uses the occasion as a powerful lobbying strategy.

All in all, the action of Bu Tejo's gossiping Dian must be seen as an example of how Javanese women show their power. Bu Tejo's attempt of defeating her opponent might look cruel as if she takes everything about Dian personally. But it must be highlighted that in the concept of Javanese women's power, it must be understood that the authority is not shown formally/ publicly/ impersonally. In contrast, for them, the personal is political. ${ }^{39}$

In other words, power can be established personally. In consequence, Bu Tejo's negative attitude towards Dian can be seen from a different perspective because Bu Tejo's gossip about Dian is a political tactic. Bu Tejo's gossip in Tilik matches with the concept of power

\footnotetext{
${ }^{38}$ Handayani and Novianto, 157.

${ }^{39}$ Handayani and Novianto, 204.
} 
proposed by Handayani and Novianto ${ }^{40}$. Power for Javanese women means the ability to persuade, take a decision, and also the competence to dominate an arrangement. Through gossip, Bu Tejo persuades the villagers to ask the sick $\mathrm{Bu}$ Lurah to resign. She also decides who is the best candidate for the upcoming lurah by belittling Dian and Bu Lurah's competence. Lastly, she also dominates all the arrangements of what's the best for the village in the future by the time $\mathrm{Bu}$ Lurah resigns.

Ultimately, the findings above showed that gossips in Tilik movie portrays power, specifically the power of Javanese women. In contrast with the study proposed by Christina which believed that the indirect speech acts depict insecurity as her husband plans to join the upcoming sub-district head election. ${ }^{41}$ Yet, aligned with previous research, gossip in Tilik movies becomes an instrument of power, ${ }^{42}$ and the weapon of choice in the female arsenal. ${ }^{43}$

Furthermore, $\quad \mathrm{Bu} \quad$ Tejo's confrontational attitude toward Dian can be interpreted as a political ploy, because the personal is political for Javanese women. Finally, Bu Tejo's behavior of gossiping about Dian corresponds to the

\footnotetext{
${ }^{40}$ Handayani and Novianto, 157, 204-205.

${ }^{41}$ Christina, "The Analysis of Bu Tejo's Language in Short Movie 'Tilik."' 66.

42 Greta Bergrun Johannesdottir et al., "What's Love Got to Do with It? Love-Life Gossip and Migration Intentions in Rural Iceland," Journal of Rural Studies $87 \quad$ (2021): 236-42, https://doi.org/10.1016/j.jrurstud.2021.09.019.

${ }^{43}$ Francis T. McAndrew, "The 'Sword of a Woman': Gossip and Female Aggression," Aggression and Violent Behavior 19, no. 3 (2014): 196-99.
}

way Javanese women play the power game. Bu Tejo improves her knowledge and power by gossiping in srawung (socialization) and gaining key concerns. Finally, it is apparent that Javanese women develop power by playing within the power structure rather than challenging it. ${ }^{44}$

These findings are in line with Geertz's assertion (as cited in Handayani and Novianto) that the consequences of Javanese female dominance may be felt across society as a "women's dominance network." 45 Women identify their authority with other women or others who are related to them, resulting in a powerful network in which women's domination becomes an actual form of power. Bu Tejo's gossip strengthen Denys Lombard's statement (as cited in Handayani and Novianto) which stated that while operating behind the scenes, the authority of Javanese women is still effective and has deep roots in their social groupings. $^{46}$

\section{Conclusion}

The gossiping act in Tilik movie portrays power, specifically the power of Javanese women. In this movie, the character Dian is treated as a contender, a rival in the upcoming election. The goal of gossiping Dian is to exclude her as a competitor from a social group and damage the competitor's ability to maintain a reliable social network of her

\footnotetext{
${ }^{44}$ Handayani and Novianto, Kuasa Wanita Jawa. 203.

${ }^{45}$ Handayani and Novianto, 14.

${ }^{46}$ Handayani and Novianto, Kuasa Wanita Jawa. 14
} 
own. As a result, in line with the earlier study, gossip in Tilik movie becomes a favorite weapon in the female armory.

Then, the existence of gossip in Tilik movie can be analyzed with the concept of power among Javanese women proposed by Handayani and Novianto. Bu Tejo's negative attitude towards Dian can be seen as a political tactic for Javanese women, and the personal is political means power can be determined personally because diplomacy and bargaining take place in the most private of spaces. Bu Tejo's bargaining and diplomacy happen in her women network, during the trip from the village to the hospital. Thus, Bu Tejo's act of gossiping Dian matches with the concept of how Javanese women play the game of power. Through gossip, Bu Tejo had persuaded the locals, chosen the best candidate for the forthcoming lurah, and dominated all arrangements for the village's future.

Lastly, it should be noted that this study aimed to see the relation between gossip and power under the context of Javanese women. This study uncovered another purpose of gossip, particularly in the lives of Javanese women. Thus, for further research, it is highly suggested to analyze further the content of gossip verbatim and study them further by applying the structure pattern of Ngrasani' Gossiping' by Javanese Women in Indonesia. Thus, in the future, the cultural behavior of Javanese women in Indonesia could be learned in-depth.

\section{References}

Archer, John. "Sex Differences in Aggression in Real-World Settings: A Meta Analytic Review." Review of General Psychology 8, no. 4 (2004): 291-322.

Bakhtin, Mikhail Mikhailovich. Art and Answerability. Edited by Michael Holquist and Vadim Liapunov. Austin: The University of Texas Press, 1990.

Bakhtin, Mikhail Mikhailovich. "The Dialogic Imagination: Four Essays." In Theory of the Novel, edited by Michael McKeon, 321-54. Baltimore: The John Hopkins University Press, 2000.

Baumeister, Roy F., Liqing Zhang, and Kathleen D. Vohs. "Gossip as Cultural Learning." Review of General Psychology 8, no. 2 (2004): 111-21. https://doi.org/10.1037/10892680.8.2.111.

Christina. "The Analysis of Bu Tejo's Language in Short Movie 'Tilik."' Metaphor 3, no. 1 (2020): 56-67.

Cross, Catharine, and Anne C. Campbell. "Violence and Aggression in Women." In The Evolution of Violence, edited by Todd K. Shackelford and Ranald D. Hansen, 211-32. New York: Springer, 2014.

Farley, Sally D. "Is Gossip Power? The Inverse Relationships between Gossip, Power, and Likability." European Journal of Social Psychology 41, no. 5 (2011): 57479. https://doi.org/10.1002/ejsp.821.

Farley, Sally D. "On the Nature of Gossip, Reputation, and Power Inequality." In The Oxford Handbook of Gossip and Reputation, edited by Francesca Giardini and Rafael Wittek, 343-58. New York: Oxford University Press, 2019.

Foster, Eric K. "Research on Gossip: Taxonomy, Methods, and Future Directions." Review of General 
Psychology 8, no. 2 (2004): 78-99. https://doi.org/10.1037/1089-

2680.8.2.78.

Giardini, Francesca, and Rafael Wittek. "Introduction: Gossip and Reputation-A Multidisciplinary Research Program." In The Oxford Handbook of Gossip and Reputation, edited by Francesca Giardini and Rafael Wittek, 1-24. New York: Oxford University Press, 2019.

Handayani, Christina S., and Ardhian Novianto. Kuasa Wanita Jawa. Edited by Retno Suffatni. Yogyakarta: PT LKiS Printing Cemerlang, 2004.

Huskey, Richard. "Gossip: More than Just Trash Talk." Current Biology 31, no. 12 (2021): 783-86. https://doi.org/10.1016/j.cub.2021.04 .048 .

Inayaturrobbani, Fakhirah. "Memahami Fungsi Gosip dalam Masyarakat Melalui Film Pendek 'Tilik.'” TONIL: Jurnal Kajian Sastra, Teater dan Sinema 17, no. 2 (2020): 41-54. https://doi.org/10.24821/tnl.v17i2.43 53.

Johannesdottir, Greta Bergrun, Thoroddur Bjarnason, Aileen Stockdale, and Tialda Haartsen. "What's Love Got to Do with It? Love-Life Gossip and Migration Intentions in Rural Iceland." Journal of Rural Studies 87 (2021): 236-42. https://doi.org/10.1016/j.jrurstud.202 1.09.019.

Lestari, Prembayun Miji, Djatmika, Sumarlam, and Dwi Purnanto. "The Structure Pattern of Ngrasani 'Gossiping' by Javanese Women in Indonesia." Australasian Journal of Educational Technology 35, no. 1 (2019): 116-29.
McAndrew, Francis T. "The 'Sword of a Woman': Gossip and Female Aggression." Aggression and Violent Behavior 19, no. 3 (2014): 196-99.

McAndrew, Francis T. "The 'Sword of a Woman': Gossip and Female Aggression." Aggression and Violent Behavior 19, no. 3 (2014): 196-99. https://doi.org/10.1016/j.avb.2014.04 .006.

McAndrew, Frank, and Megan A. Milenkovic. "Of Tabloids and Family Secrets: The Evolutionary Psychology of Gossip." Journal of Applied Social Psychology 32, no. 5 (2002): 1064-82. https://doi.org/10.1111/j.15591816.2002.tb00256.x.

Merdeka, Moyang Kasih Dewi. "Tilik dan Riwayat Film Pendek Kita." Tempo, September 4, 2020. https://majalah.tempo.co/read/seling an/161344/tilik-dan-riwayat-filmpendek-kita.

Nurhablisyah, Nurhablisyah, and Khikmah Susanti. "Analisis Isi 'Tilik' Sebuah Tinjauan Narasi Film David Bordwell." Jurnal IImu Komunikasi UHO: Jurnal Penelitian Kajian IImu Komunikasi dan Informasi 5, no. 4 (2020): 315-29. https://doi.org/10.52423/jikuho.v5i4. 14460.

Pambudy, Ninuk M. "Menilik Lagi "Tilik"." Kompas.Id, September 12, 2020. https://www.kompas.id/baca/opini/20 20/09/12/menilik-lagi-tilik/.

Suryakusuma, Julia. "'Tilik', Sexist Stereotypes and Our Collective Insanity." The Jakarta Post, September 16, 2020. https://www.thejakartapost.com/aca demia/2020/09/16/tilik-sexiststereotypes-and-our-collectiveinsanity.html. 